\title{
Renal Metabolism of Amino Acids and Ammonia in Subjects with Normal Renal Function and in Patients with Chronic Renal Insufficiency
}

\author{
alberto Tizianello, Giacomo De Ferrari, Giacomo Garibotto, \\ Giovanna Gurreri, and Cristina Robaudo, Istituto Scientifico di \\ Medicina Interna, Servizio di Nefrologia, University of Genoa, 16132, \\ Genoa, Italy
}

\begin{abstract}
A B S T RA C T The net renal metabolism of amino acids and ammonia in the post absorptive state was evaluated in subjects with normal renal function and in patients with chronic renal insufficiency by measuring renal uptake and release, and urinary excretion of free amino acids and ammonia. In normal subjects the kidney extracts glutamine, proline, citrulline, and phenylalanine and releases serine, arginine, taurine, threonine, tyrosine, ornithine, lysine, and perhaps alanine. The renal uptake of amino acids from arterial blood occurs by way of plasma only, whereas approximately a half of amino acid release takes place by way of blood cells. Glycine is taken up from arterial plasma, while similar amounts of this amino acid are released by way of blood cells. In the same subjects total renal ammonia production can be largely accounted for by glutamine extracted.

In patients with chronic renal insufficiency $(a)$ the renal uptake of phenylalanine and the release of taurine and ornithine disappear; $(b)$ the uptake of glutamine and proline, and the release of serine and threonine are reduced by $80-90 \%$; (c) the uptake of citrulline and the release of alanine, arginine, tyrosine, and lysine are reduced by $60-70 \% ;(d)$ no exchange of glycine is detectable either by way of plasma or by way of blood cells; (e) exchange of any other amino acid via blood cells disappears, and $(f)$ total renal ammonia production is reduced and not more than $35 \%$ of such production can be accounted for by glutamine extracted, so that alternative precursors must be used. A $140 \%$ excess of nitrogen release found in the same patients suggests an intrarenal protein and peptide breakdown, which eventually provides free amino acids for ammonia production.
\end{abstract}

Portions of the data reported in this paper appeared in an abstract presented at the VII International Congress of Nephrology, Montreal, 18-23 June, 1978.

Received for publication 7 March 1979 and in revised form 3 January 1980.

\section{INTRODUCTION}

In normal mammals in the post absorptive state the kidney seems to play a substantial metabolic role for a limited number of amino acids (AA). ${ }^{1}$ It is well known that this organ is an important site for the disposal of glutamine, which is used mainly for the production of ammonia, the most important buffer for strong acid excretion (1). In addition, the kidney is the almost exclusive site for the synthesis of serine $(2,3)$ which, at least in part, could derive from glycine extracted from the arterial blood (3). Finally, the kidney seems to release alanine and cysteine $(2,4)$. Whether chronic renal insufficiency (CRI) induces alterations in the net metabolism of some AA across the kidney is obscure. The only available data show that, in this clinical status, patients with still relatively high glomerular filtration rates (GFR) and ammonia production have a negligible renal extraction of glutamine from arterial plasma, certainly not sufficient to account for ammonia produced (5). On the other hand, there is no information on alternative precursors used by the kidney for ammonia formation in this condition.

Studies presented in this report were designed to evaluate the net AA and ammonia metabolism across the kidney in subjects with normal renal function and in patients with CRI. The study was performed by measuring renal uptake or release and urinary excretion of AA and ammonia. Considering the role of blood cells in the exchange of AA across many organs (6), AA determinations were carried out both on whole blood and plasma.

\section{METHODS}

Patients. Two groups of patients were studied and are described in Table I. The first group had arterial hypertension

${ }^{1}$ Abbreviations used in this paper: AA, amino acids; A-RV, arterial-renal venous; CRI, chronic renal insufficiency; GFR. glomerular filtration rate; Hct, hematocrit; $\mathrm{PAH}, \mathrm{Na}$ paraaminohippurate. 


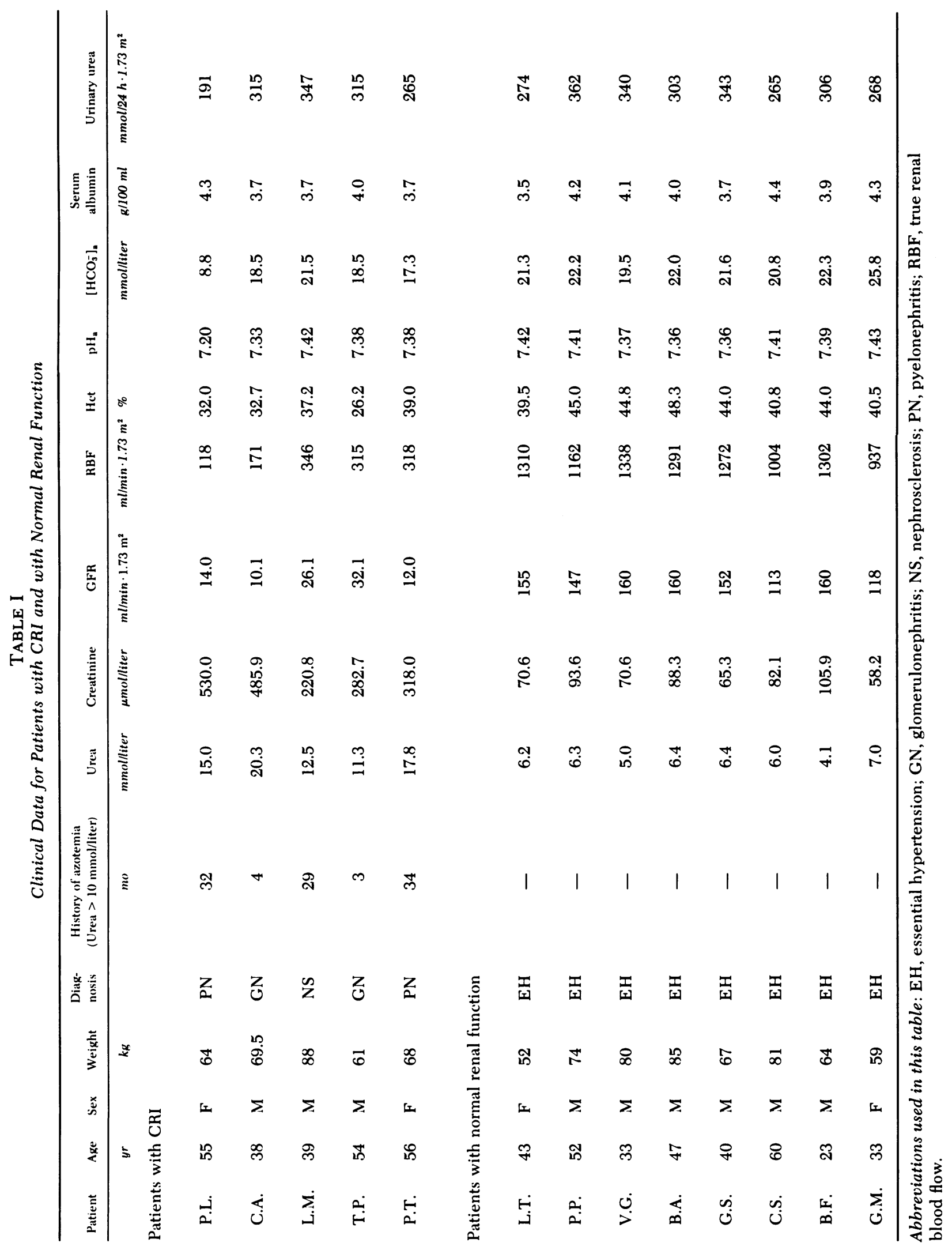


with mean blood pressures ranging from 133 to $160 \mathrm{~mm} \mathrm{Hg}$. Routine hematological tests, serum, and urine electrolyte concentrations, acid-base measurements, urinalysis, and renal function tests were normal. The rapid sequence intravenous pyelography showed a unilateral delayed appearance time of the contrast material and a persistent hyperconcentration of it. However, no significant difference in renal size was present. The subjects were on a diet that provided $30-3.5 \mathrm{kcal}$ and $0.70-0.85 \mathrm{~g}$ of protein $/ \mathrm{kg}$ body wt per $\mathrm{d}$. In all patients a renal vein catheterization was considered necessary for diagnostic purposes to determine plasma renin activity. Medications were discontinued at least $15 \mathrm{~d}$ before renal vein catheterization. The final diagnosis was benign essential hypertension.

The second group consisted of five patients with CRI.A mild azotemia had been present from 3 mo to $3 \mathrm{y}$. All patients were in good nutritional balance and were actively employed at the time of the study. They had no history or evidence of congestive heart failure, pulmonary, or hepatic diseases or diabetes mellitus. Serum sodium and potassium were in the normal range. Proteinuria was lower than $0.5 \mathrm{~g} / 24 \mathrm{~h}$ in four patients and was $1 \mathrm{~g} / 24 \mathrm{~h}$ in one patient (C.A.). Urine cultures were repeatedly negative. All patients were on a diet strictly comparable with that assumed by the control group. Two patients (L.M. and T.P.) had severe hypertension and elevated renin plasma activity, so that a renal vein catheterization for renin activity determination was useful for diagnostic purposes. The other three patients showed bone alterations that were more severe than could be expected on the basis of degree and duration of their renal insufficiency and that were attributed to hyperparathyroidism. Innominate, internal jugular and thyroid veins catheterization for parathormone measurements was carried out to localize the hyperfunctioning parathyroid tissue, in view of a possible parathyroidectomy. In the patients with severe hypertension, the intravenous pyelography showed a unilateral delayed appearance time and a persistent hyperconcentration of the contrast material. In all five patients the renal size was normal or slightly reduced without any unilateral disparity in renal mass.

Patients of both groups were informed of the nature, purpose, procedure, and possible risks before giving their voluntary consent.

Procedure. All patients were studied in the post absorptive state, after a 12-14-h overnight fast. A Teflon catheter was inserted percutaneously into a peripheral artery to measure acidbase status and arterial AA and ammonia levels. A Cobra No. 6 or $7 \mathrm{~S}$ catheter (Cook, Inc., Bloomington, Ind.) was then guided under fluoroscopic control through a femoral vein to a renal or an internal jugular vein. In this last circumstance, during removal, the catheter was threaded into the renal veins. The catheters were kept patent by flushing with saline intermittently. The position of the catheter was ascertained visually with image intensification before each blood withdrawal. Arterial blood pressure and electrocardiogram were continuously monitored during the study.

An intravenous infusion of $\mathrm{Na}$ thiosulphate and $\mathrm{Na}$ paraaminohippurate (PAH) was started after the administration of a priming dose of $\mathrm{PAH}(2.5-3 \mathrm{mmol})$. The infusion was kept at a constant flow rate (Na thiosulphate $0.8 \mathrm{mmol} / \mathrm{min}$ and $\mathrm{PAH}$ $0.09 \mathrm{mmol} / \mathrm{min}$ ) and two or three sequential clearance periods, of $20 \mathrm{~min}$ each, were obtained. The correct position of the catheter in the renal vein was verified by calculating the renal extraction of PAH and oxygen. Oxygen extraction, calculated as $\left(\right.$ oxygen $_{a}-$ oxygen $\left._{v}\right) /$ oxygen $_{a} \times 100$, was used during catheterization as a quick test for checking with a good approximation the correct position of the catheter. The combined measurement of renal PAH and oxygen extraction was particularly useful in patients with renal insufficiency, as low values of PAH extraction could depend either on renal alterations or on an in- correct catheter position, but a low oxygen extraction definitely identified renal venous blood. During each clearance period one set of blood samples was obtained simultaneously from a peripheral artery and a renal vein for the measurement of arterial-renal venous (A-RV) differences of $\mathrm{AA}$ and ammonia.

Blood was withdrawn by heparinized syringes kept in ice. During the study urine was collected via a cannula under min eral oil and then stored at $-25^{\circ} \mathrm{C}$ in bottles that containe ${ }^{2}$ th mol.

Analytical methods. AA were determined both on whole. blood and plasma. Perchloric acid (0.75 mol/liter) was used for blood protein precipitation. For individual AA determination, whole blood proteins were precipitated within $60 \mathrm{~min}$ and plasma proteins within $2 \mathrm{~h}$ from the blood withdrawal. An aliquot of the supernate was neutralized with a buffered solution. stored at $-25^{\circ} \mathrm{C}$, and used for enzymatic assay of glutamine, glutamate, and aspartate within $30 \mathrm{~h}$. Another aliquot was stored at $-25^{\circ} \mathrm{C}$ and used for the determination of 19 additional $A A$ within 3 mo. The influence of specimen storage at $-25^{\circ} \mathrm{C}$ : for such a period of time does not affect AA levels as shown by our laboratory and reported in the literature (7).

Reliability of procedures followed for sample preparation was verified by studying blood samples obtained from nomal controls and from patients with C.RI. No difference in AA levels measured in whole blood, plasma, and blood cells (three blood samples from controls and three from patients) was observed when samples, deproteinized immediately after the withdrawal, and samples deproteinized 60 min (whole blood and blood (ells) or $2 \mathrm{~h}$ (plasma) after the withdrawal were compared. For such a comparison peripheral venous blood and renal venous blood was used, since in venous blood a potential diseguilibrium between plasma and blood cell proportions for several AA could be induced by muscle and kidney. Furthermore, the same studies showed that the AA levels measured in whole blood fairly matched the sum of AA contributions measured in plasma and in blood cells; there was no change during periods of time considered. In other experiments a 20 -A A solution in amounts sufficient to increase significantly blood AA levels was added to six blood samples (three from normal controls and three from patients with (CRI) immediately after the withdrawal. Controls were run by adding saline to additional samples of the same blood. Alicuots of blood were processed immediately and $1 \mathrm{~h}$ after the addition of the AA solution: AA levels in plasma and in whole blood were constant within the 1-h period considered. These data suggest that no change in AA distribution between plasma and blood cells took place during the same period.

AA analyses were performed at least in triplicate by automated ion-exchange chromatography on a Beckman Multichrom B AA analyzer (Beckman Instruments, Inc.. Fullerton. Calif.). When $\mathrm{AA}$ were measured on whole blood with this technique, the supernate was neutralized and treated with $\mathrm{N}_{\text {a }}$ sulphite immediately before the assay to remove glutathione. This procedure causes a loss of methionine and cysteine, which are therefore not reported. Glutamine was estimated enzymatically according to the method described by $\mathrm{L}$.und ( 8 ). modified for Huorometer measurements (Farrand A 4. Farrand Optical Co., Inc., Valhalla, X. Y.). Recovery of glutamine, added to whole blood or plasma, was determined for each assay: the recovery ranged from 97 to $102 \%$. (ilutamate and aspartate were determined with the methods used by Graham and Aprison (9). For these assays the samples, blanks and standards were done in triplicate. AA in urine were determined by ionexchange chromatography on a Multichrom B after deproteination.

For blood ammonia determination, whole blood was deproteinized at $+4^{\circ} \mathrm{C}$ with $\mathrm{Nat}^{\circ}$ tungstate and sulphuric acid immediately after the withdrawal. The protein-free supernate wat 
stored at $-25^{\circ} \mathrm{C}$ and assayed according to Chaney and Marbach (10) within $12 \mathrm{~h}$. An eightfold concentration of phenol and hypochlorite reagents was used. The same method was followed for the measurements of ammonia in urine.

$\mathrm{Na}$ thiosulphate concentration in plasma and urine was determined according to Brun (11). PAH concentration in plasma and urine was measured as suggested by Smith et al. (12).

Blood and urine $\mathrm{pH}$ and $\mathrm{PaCO}_{2}$ were estimated at $37^{\circ} \mathrm{C}$ with PHM 72/BMS 3 apparatus (Radiometer Co., Copenhagen, Denmark). Blood [ $\left.\mathrm{HCO}_{3}^{-}\right]$was calculated using the Henderson-Hasselbalch equation. $\mathrm{SaO}_{2}$ was measured with an Hellige oximeter (American Optical Corp., Scientific Instrument Div., Buffalo, N. Y.). Hematocrit (Hct) was determined by a microcapillary procedure.

Calculations. Renal arterial plasma flow was calculated from clearance and extraction of PAH using the equation of Wolf (13). Renal arterial blood flow was calculated from renal plasma flow and arterial Hct. Renal blood cell flow was obtained by subtracting plasma flow from blood flow.

The levels of AA and ammonia in whole blood and of AA in plasma was calculated using a dilution factor corresponding to the dilution of the sample after deproteination and neutralization. A water content of 80 and $93 \%$, respectively for whole blood and plasma was taken into account for the calculation of the dilution factor (14). The levels of AA in blood cells were calculated by the following formula (15):

$$
[\mathrm{AA}]_{\mathrm{BC}}=\frac{[\mathrm{AA}]_{\mathrm{WB}}-\left[\left(1-\frac{\mathrm{Hct}}{100}\right) \times[\mathrm{AA}]_{\mathrm{PI}}\right]}{\mathrm{Hct} / 100}
$$

where: $[\mathrm{AA}]_{\mathrm{BC}}=$ level of $\mathrm{AA}$ in blood cells ( $\left.\mu \mathrm{mol} / \mathrm{liter}\right)$; $[\mathrm{AA}]_{\mathrm{WB}}=$ level of AA in whole blood $(\mu \mathrm{mol} / \mathrm{liter})$, and $[\mathrm{AA}]_{\mathrm{P} 1}$ $=$ level of AA in plasma ( $\mu \mathrm{mol} / \mathrm{liter})$.

The coefficients of variation for individual AA analyses were: $\pm 2 \%$ for glutamine; $\pm 3 \%$ for glutamate, leucine, tyrosine, phenylalanine, and 3 -methylhistidine; $\pm 4 \%$ for aspartate, glycine, alanine, valine, methionine, citrulline, and arginine; $\pm 5 \%$ for serine, isoleucine, ornithine, lysine, and histidine; $\pm 7 \%$ for threonine and proline; and $\pm 9 \%$ for $\alpha$-aminobutyric acid.

Net extraction (+) or net release (-) of individual AA and ammonia by the kidney were calculated by the following formula: $\mathbf{M}=\left(\mathrm{F}_{\mathrm{a}} \times \mathrm{S}_{\mathrm{a}}\right)-\mathrm{S}_{\mathrm{v}}\left(\mathrm{F}_{\mathrm{a}}-\mathrm{F}_{\mathrm{u}}\right)-\left(\mathrm{F}_{\mathrm{u}} \times \mathrm{S}_{\mathrm{u}}\right)$, where: $\mathbf{M}=$ net uptake or release $\left(\mu \mathrm{mol} / \mathrm{min} \cdot 1.73 \mathrm{~m}^{2}\right), \mathrm{F}_{\mathrm{a}}=$ renal arterial blood flow $\left(\mathrm{ml} / \mathrm{min} \cdot 1.73 \mathrm{~m}^{2}\right), \mathrm{F}_{\mathrm{u}}=$ urinary flow $\left(\mathrm{ml} / \mathrm{min} \cdot 1.73 \mathrm{~m}^{2}\right)$, $S_{a}=$ arterial level of metabolite $(\mu \mathrm{mol} / \mathrm{ml}), S_{v}=$ renal venous level of metabolite $(\mu \mathrm{mol} / \mathrm{ml})$, and $S_{u}=$ urinary level of metabolite $(\mu \mathrm{mol} / \mathrm{ml})$.

The total ammonia production was obtained by summing the values for renal venous ammonia release and urine ammonia excretion.

The $\mathrm{N}$ balance across the kidney here reported was calculated by subtracting $\mathrm{N}$ contributed by individual AA significantly released, plus $\mathrm{N}$ contributed by total ammonia produced, from $\mathrm{N}$ contributed by individual AA significantly extracted (i.e., $1 \mu \mathrm{mol}$ of citrulline is considered to have 3 $\mu \mathrm{mol}$ of $\mathrm{N} ; 1 \mu \mathrm{mol}$ of glutamine, $2 \mu \mathrm{mol}$ of $\mathrm{N} ; 1 \mu \mathrm{mol}$ of alanine, $1 \mu \mathrm{mol}$ of $\mathrm{N} ; 1 \mu \mathrm{mol}$ of ammonia, $1 \mu \mathrm{mol}$ of $\mathrm{N}$; etc.).

Controls and patients with CRI were compared by analysis of variance by using a completely randomized design. A randomized block design was applied to the analysis of variance for the paired data. This method was followed to ascertain if the A-RV differences were significantly different from zero. Relationships between citrulline uptake and arginine release and between arterial level of each individual AA and their renal re- lease or uptake were studied by analysis of linear regression and correlation (16). Values are given as mean \pm 1 SE.M.

\section{RESULTS}

A-RV differences and net balance across the kidney of free AA in whole blood, plasma and blood cells in subjects with normal renal function and in patients with CRI. In normal subjects (Table II) AA determinations in whole blood show significant positive A-RV differences only for glutamine, proline, citrulline and phenylalanine, indicating a renal uptake of these AA. The rate of glutamine uptake accounts for $58 \%$ of the total AA extraction by the kidney. In the same subjects, analysis of plasma demonstrates a significant uptake of glycine also. Since the rates of glutamine, proline, citrulline, and phenylalanine uptakes are strictly comparable both in whole blood and in plasma, it follows that the kidney takes up these AA only from arterial plasma. Conversely, in the case of glycine, which is extracted from plasma but not from whole blood, blood cells must play an important role in the exchange of this AA across the kidney.

A-RV differences determined in whole blood are negative for taurine, threonine, serine, tyrosine, ornithine, lysine, and arginine, indicating a release into the circulation of these AA. The release of alanine is only at the borderline of significance $(P<0.1)$, likely depending on a high variability among subjects. The rate of serine release is responsible for $37 \%$ of the total AA output by the kidney. In the same subjects serine and ornithine are released into the renal venous blood only by way of plasma; taurine, threonine, and lysine only by way of blood cells. Alanine, tyrosine, and arginine are added to the renal veins both by way of plasma and blood cells.

In patients with CRI (Table III) AA analyses both on whole blood and on plasma demonstrate a significant decrease in renal extraction of glutamine, proline, and citrulline in comparison with controls. As in normal subjects, these AA are extracted by the kidney only from arterial plasma. Phenylalanine extraction is not detectable. Glycine uptake from plasma and glycine release by way of blood cells disappear completely. In patients with CRI, as in normal subjects, A-RV differences on whole blood are negative for threonine, serine, alanine, tyrosine, lysine, and arginine, indicating a release of these AA. However the rates of release of these AA are variously decreased. The comparison between the rate of release obtained from whole blood and from plasma measurements indicate that these AA are released into renal venous blood via plasma only. Consequently, in contrast to normal controls, in CRI no role is played by blood cells in such exchange. Again in contrast to controls, taurine and ornithine release disappears, whereas a statistically detectable output of leucine occurs.

In patients with CRI there are increases in whole 


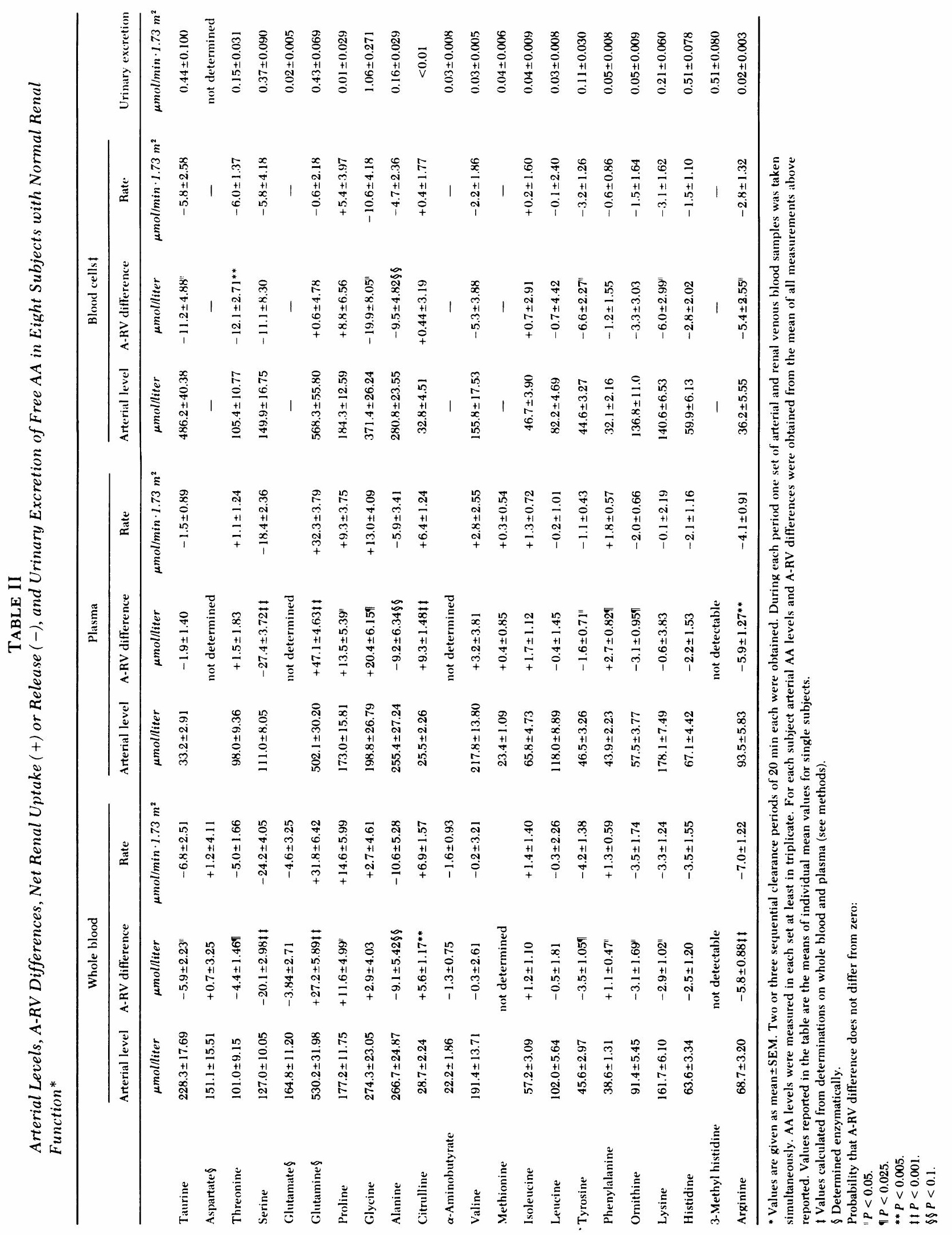




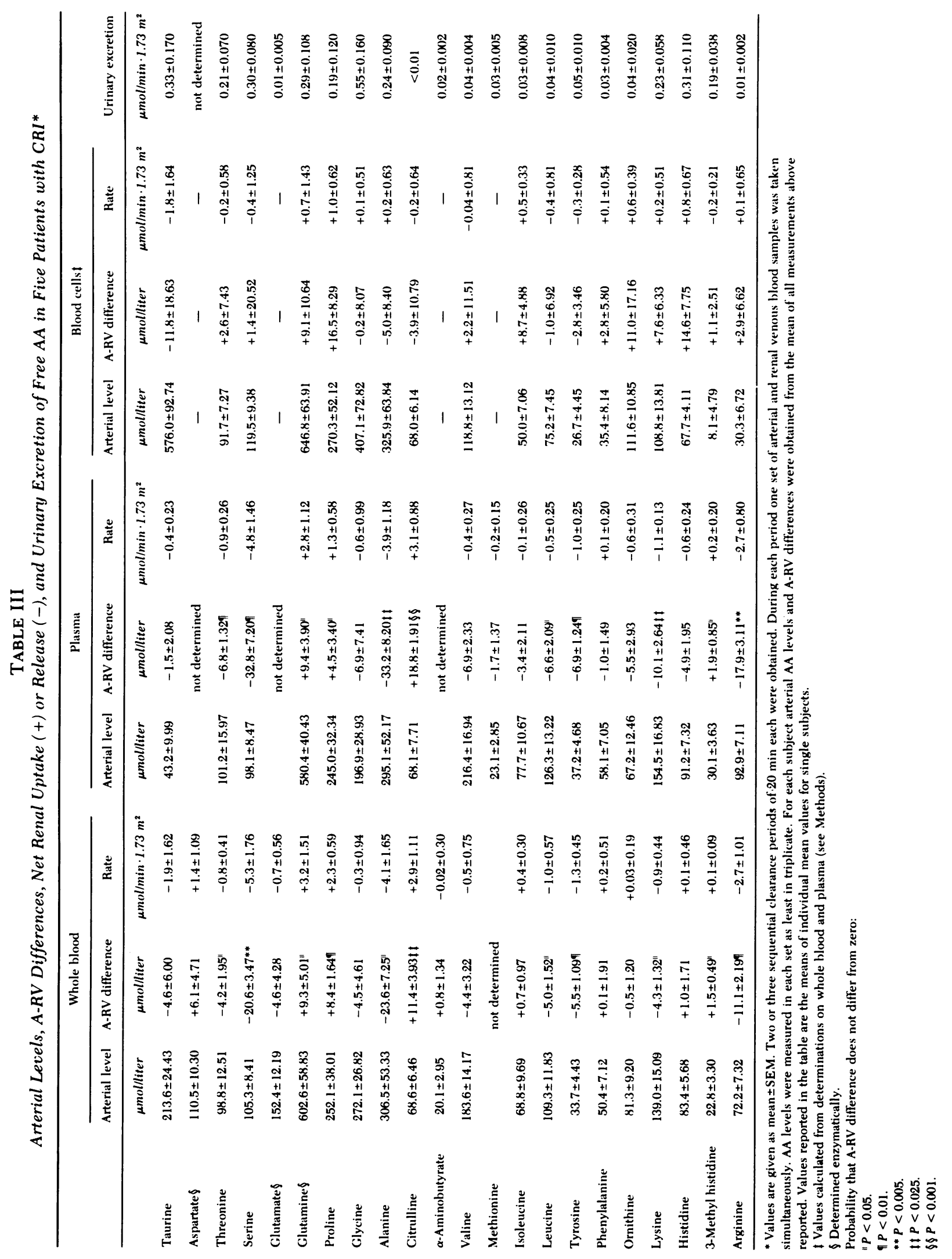


blood arterial level of 3-methylhistidine, proline ( $P$ $<0.01)$, citrulline $(P<0.001)$, histidine $(P<0.005)$, and perhaps glutamine $(P<0.1)$ and phenylalanine $(P<0.1)$, whereas there are decreases of aspartate $(P<0.005)$, tyrosine $(P<0.005)$, and perhaps serine $(P<0.1)$ and lysine $(P<0.1)$.

Excretion of most urinary AA was negligible in both normal and pathological conditions. Differences in urinary output at the borderline of significance $(P<0.1)$ are observed only for 3-methylhistidine, which is excreted in lower amount in CRI, and for proline, which, conversely, is excreted in higher amount.

Table IV gives the rates of renal AA extraction and release per $100 \mathrm{ml}$ of GFR. It is evident that the extraction of citrulline and the release of alanine, leucine, tyrosine, and arginine appear markedly increased, whereas the extraction of glutamine and proline, and the release of threonine, serine and lysine are unchanged in comparison with normal controls.

Fig. 1 depicts the relationship between citrulline extraction and arginine release in subjects with normal renal function and in patients with CRI. A highly significant direct linear correlation was observed ( $P$ $<0.001)$.

Fig. 2 shows the relationship between the release into the renal veins of tyrosine and the arterial level of the same AA in subjects with normal renal function and in patients with CRI. A significant correlation was found $(P<0.05)$. No significant correlation between the arterial level of other AA and their renal metabolism was observed.

Renal ammonia production in subjects with normal renal function and in patients with CRI. In normal subjects total renal ammonia production was $37.8 \pm 3.08$ $\mu \mathrm{mol} / \mathrm{min}$, almost equally partitioned between urine and renal venous blood (Table $\mathrm{V}$ ). Both urinary ammonia and ammonia added to the renal venous blood are reduced in patients with CRI. Consequently, total renal ammonia production is decreased. If total am- monia production is expressed per $100 \mathrm{ml}$ of GFR, the rate of ammonia production per unit of GFR is much greater in patients with CRI than in subjects with normal renal function. The distribution of ammonia produced between urine and renal venous blood is not different from normal controls and this finding is likely dependent on strictly comparable urinary $\mathrm{pH}$ and flow.

Nitrogen extraction and release by the kidney in subjects with normal renal function and in patients with CRI (Table VI). In normal conditions $\mathrm{N}$ contributed by AA extracted, and $\mathrm{N}$ contributed by AA and ammonia released by the kidney are well balanced. On the contrary, patients with CRI show a $140 \%$ excess of $\mathrm{N}$ added to the renal venous blood $(P<0.025)$.

\section{DISCUSSION}

Findings presented here confirm previous observation by Owen and Robinson (2) demonstrating that in normal conditions the human kidney extracts glutamine and proline and releases large amounts of serine into the renal veins. Our data provide stronger statistical evidence for the release of arginine. Alanine output is at the borderline of statistical significance in our study, whereas it is statistically significant in Owen and Robinson's normal subjects. On the contrary, this AA is significantly extracted by the kidney in starved man (17). In addition, we obtained several new results. A significant citrulline and phenylalanine extraction and a taurine, threonine, lysine, tyrosine, and ornithine release are observed. The detection of the renal release of a greater number of AA in comparison with data by Owen and Robinson is partly due to the important role played by blood cells in the handling of AA by the kidney. For the same reason, the net balance of glycine across the kidney is not different from zero.

The data presented here demonstrate that renal uptake of AA from arterial blood occurs by way of plasma only, whereas AA release by the kidney to renal venous

TABLE IV

Renal AA Extraction and Release per $100 \mathrm{ml}$ of GFR in Subjects with Normal Renal Function and in Patients with CRI*

\begin{tabular}{|c|c|c|c|c|c|c|c|c|c|c|c|c|c|}
\hline & $\begin{array}{l}\text { Glutamine } \\
\text { extraction }\end{array}$ & $\begin{array}{l}\text { Proline } \\
\text { extraction }\end{array}$ & $\begin{array}{l}\text { Citrulline } \\
\text { extraction }\end{array}$ & $\begin{array}{c}\text { Phenylalanine } \\
\text { extraction }\end{array}$ & $\begin{array}{l}\text { Serine } \\
\text { release }\end{array}$ & $\begin{array}{l}\text { Alanine } \\
\text { release }\end{array}$ & $\begin{array}{l}\text { Taurine } \\
\text { release }\end{array}$ & $\begin{array}{l}\text { Arginine } \\
\text { release }\end{array}$ & $\begin{array}{c}\text { Threonine } \\
\text { release }\end{array}$ & $\begin{array}{l}\text { Tyrosine } \\
\text { release }\end{array}$ & $\begin{array}{l}\text { Ornithine } \\
\text { release }\end{array}$ & $\begin{array}{l}\text { Lysine } \\
\text { release }\end{array}$ & $\begin{array}{l}\text { Lencine } \\
\text { releate }\end{array}$ \\
\hline & \multicolumn{13}{|c|}{$\mu \mathrm{mol} / \mathrm{min} / 100 \mathrm{ml} \mathrm{GFR}$} \\
\hline $\begin{array}{l}\text { Subjects with } \\
\text { normal renal } \\
\text { function (8) }\end{array}$ & $\begin{array}{l}22.8 \\
\pm 5.23\end{array}$ & $\begin{array}{c}9.5 \\
\pm 4.04\end{array}$ & $\begin{array}{c}4.6 \\
\pm 0.96\end{array}$ & $\begin{array}{c}0.9 \\
\pm 0.39\end{array}$ & $\begin{array}{l}16.6 \\
\pm 2.55\end{array}$ & $\begin{aligned} & 7.5 \\
\pm & 4.37\end{aligned}$ & $\begin{array}{c}5.0 \\
\pm 1.81\end{array}$ & $\begin{aligned} & 4.7 \\
\pm & 0.70\end{aligned}$ & $\begin{array}{l}3.6 \\
\pm 1.17\end{array}$ & $\begin{array}{c}2.8 \\
\pm 0.85\end{array}$ & $\begin{aligned} & 2.5 \\
\pm & 1.41\end{aligned}$ & $\begin{array}{c}2.4 \\
\pm 0.85\end{array}$ & $\begin{array}{r}0.31 \\
\pm 1.50\end{array}$ \\
\hline $\begin{array}{l}\text { Patients with } \\
\text { (CRI (5) }\end{array}$ & $\begin{aligned} & 12.6 \\
\pm & 10.62\end{aligned}$ & $\begin{array}{l}13.4 \\
\pm 3.55\end{array}$ & $\begin{array}{r}12.15 \\
\pm 3.78\end{array}$ & $\begin{array}{r}0.81 \\
\pm 2.06\end{array}$ & $\begin{array}{l}25.7 \\
\pm 4.00\end{array}$ & $\begin{array}{l}30.6 \$ \\
\pm 9.10\end{array}$ & $\begin{array}{r}5.31 \\
\pm 6.69\end{array}$ & $\begin{array}{l}14.1 \\
\pm 3.21\end{array}$ & $\begin{array}{c}6.0 \\
\pm 2.64\end{array}$ & $\begin{array}{r}6.4^{4} \\
\pm 0.99\end{array}$ & $\begin{array}{r}1.4 \pm \\
\pm 1.57\end{array}$ & $\begin{aligned} & 5.0 \\
\pm & 1.67\end{aligned}$ & $\begin{aligned} & 5.2 \\
\pm & 1.99\end{aligned}$ \\
\hline
\end{tabular}

* Data are presented as mean \pm SEM. Only the AA that showed statistically significant A-RV difference's across the kidney at least in one of the two groups studied are considered.

1 Extraction or release not significantly different from zero.

$\$$ Significantly different from the corresponding value in normal subjects, $P<0.05$.

Significantly different from the corresponding value in normal subjects, $P<0.01$.

- Significantly different from the corresponding value in normal subjects, $P<0.025$. 


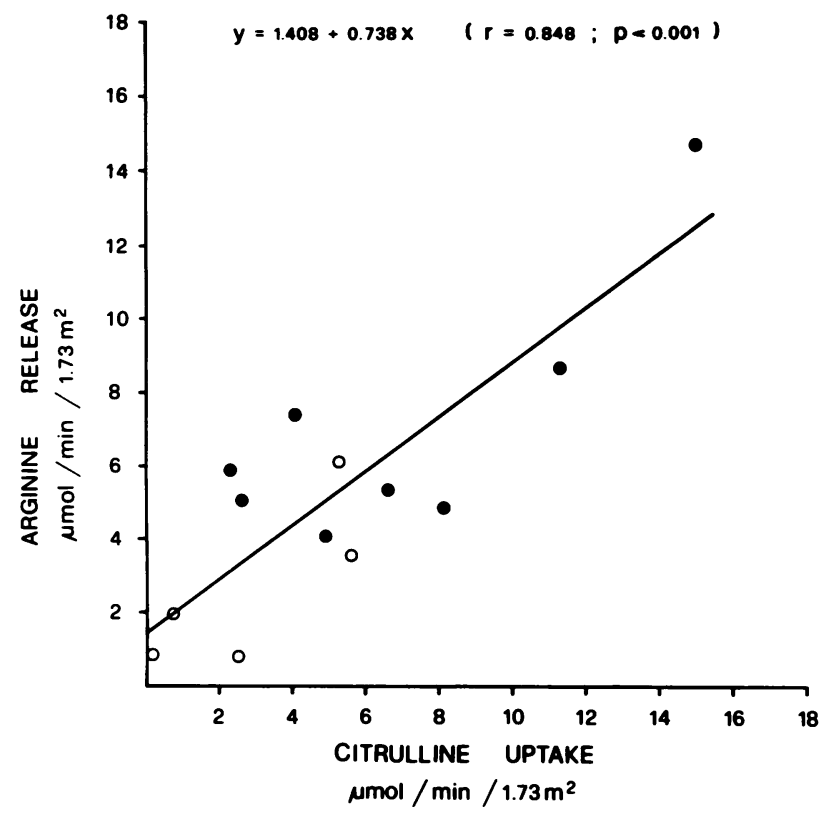

FIGURE 1 Relationships between citrulline extraction and arginine release by the kidney in eight subjects with normal renal function (solid circles) and in five patients with CRI (open circles).

blood takes place approximately a half by way of blood cells and the other half by way of plasma. Most of individual AA are released by the kidney either via plasma or via blood cells only. Others, namely alanine, tyrosine, and arginine are released both via plasma and via blood cells in parallel directions. Conversely, glycine is taken up by the kidney from arterial plasma and de-

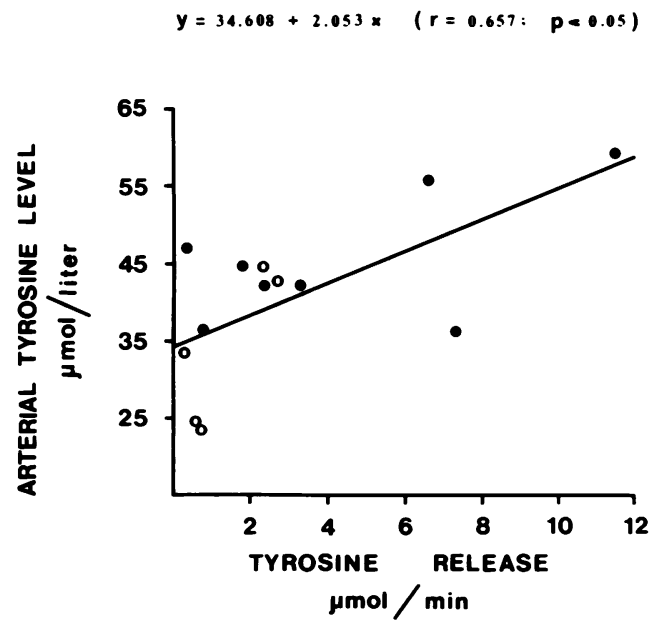

Figure 2 Relationships between tyrosine release by the kidney and arterial tyrosine levels in whole blood in eight subjects with normal renal function (solid circles) and in five patients with CRI (open circles). livered to renal venous blood via blood cells, showing opposite directions of exchange across the kidney. There is consistent evidence for a role of blood cells in AA exchanges across hepatosplanchnic bed and muscle also $(6,18,19)$. These results suggest the existence of direct AA exchanges between renal tissue and blood cells as postulated occur in dog hepatosplanchnic bed (19). Conversely, AA transfer from plasma to blood cells within the kidney seems unlikely, since human erythrocytes take up AA slowly in vitro (20). Surprisingly our data show that the role of blood cells in AA exchange across the kidney disappears in CRI. Recently a lower creatinine transfer rate into erythrocytes was shown in uremia (21). Explanations for the exchange of AA across the kidney via blood cells, its disappearance in CRI, and the related metabolic meanings are obscure. However, our findings implicate that definite conclusions on the net renal balance of AA must be drawn only from analyses carried out on whole blood.

It is well known that the extraction of glutamine by the normally functioning kidney greatly exceeds the extraction of other AA and that the extraction rate of glutamine is related to the acid-base status of the subjects, since glutamine is the major precursor used by the kidney for ammonia formation (1). The values of renal glutamine uptake in normal subjects studied here by analyses on whole blood confirm previous results obtained from plasma measurements $(2,5,22)$, as no significant extraction of glutamine from blood cells occurs across the kidney (Table II). In normal conditions the amount of glutamine extracted from blood is sufficient to account for all the ammonia produced. The ratio of ammonia production to glutamine extraction is $\sim 1$, and this suggests that only a half of $\mathrm{N}$ provided by this AA is used for ammonia synthesis, the other half likely being added to an intrarenal $\mathrm{N}$ pool used for the synthesis of other AA.

Findings reported here demonstrate that there is no renal extraction of glycine from whole blood as observed in rat (23). Actually, the lack of a glycine extraction by the kidney appears to be the result of an uptake from plasma, as already shown in starved man (17) and in acidotic dog (24), and of a concomitant addition of similar amounts of glycine to the renal venous blood by way of blood cells. The origin of glycine added to blood cells within the kidney is obscure. It is known that glycine is a component of glutathione, which is present in high concentrations in erythrocytes and in living cells (25). There is also evidence that glutathione turnover is much more rapid in kidney than in any other organ (25) and that, in vitro, glutathione degradation releases glycine within the kidney (26). Thus, a glutathione breakdown in the kidney might be an important source of glycine. Glycine so produced might be added to the renal glycine pool and partially transferred to blood cells. 
TABLE $V$

Renal Ammonia Production in Subjects with Normal Renal Function and in Patients with CRI*

\begin{tabular}{|c|c|c|c|c|c|c|}
\hline & Crine $\mathrm{pH}$ & Urine flow & Urinary $\mathrm{NH}_{4}^{+}$ & $\begin{array}{l}\mathrm{NH}_{\mathrm{i}} \text { added to } \\
\text { the renal veins }\end{array}$ & \multicolumn{2}{|c|}{ Total $\mathrm{NH}_{i}$ production } \\
\hline & & $\mathrm{ml} / \mathrm{min} \cdot 1.73 \mathrm{~m}^{2}$ & $\mu \mathrm{mol} / \mathrm{min} \cdot 1.73 \mathrm{~m}^{2}$ & $\mu \mathrm{mol} / \mathrm{min} \cdot 1.73 \mathrm{~m}^{2}$ & $\mu$ molimin $1.73 \mathrm{~m}^{2}$ & $\mu \mathrm{mol} / \mathrm{min} / 100 \mathrm{mlCFR}$ \\
\hline
\end{tabular}

* Values are given as mean \pm SEM.

\$ Significantly different from the corresponding value in normal subjects, $P<0.005$.

$\$$ Significantly different from the corresponding value in normal subjects, $P<0.025$.

Significantly different from the corresponding value in normal subjects, $P<0.001$.

Glycine from the renal pool can also be used for the synthesis of serine. In fact, glycine is the almost exclusive precursor used by the kidney for serine formation through the serine hydroxymethyltransferase pathway (EC 2.1.2.1.) (3). Results reported here indicate that the normal kidney in the postabsorptive state releases serine at a higher rate than that measured for any other AA. These data confirm previous observations in different mammals $(2,17,23,24)$. Not more than $50 \%$ of such a large amount of serine produced by the kidney can be accounted for by glycine supplied to the renal glycine pool via plasma, as confirmed by data by other authors $(2,24)$. The other $50 \%$ of serine must derive from glycine supplied to the kidney by other sources.

Our results show that in normal man large amounts of citrulline are constantly extracted by the kidney and this extraction is well correlated with the release of arginine (Fig. 1). This relationship suggests that the human kidney produces arginine from citrulline, as already demonstrated in rats both in vitro (27) and in vivo (28). Thus, the kidney shares the overall release of arginine with muscular tissue, which produces comparable amounts of arginine $(29,30)$.

\section{TABLE VI}

Renal Extraction and Release of Nitrogen Contributed by AA and Ammonia in Subjects with Normal Renal Function and in Patients with CRI*

\begin{tabular}{lccc}
\hline & $\begin{array}{c}\text { Nitrogen } \\
\text { extracted }\end{array}$ & $\begin{array}{c}\text { Nitrogen } \\
\text { released }\end{array}$ & \multicolumn{1}{c}{$\begin{array}{c}\text { Net nitrogen } \\
\text { balance }\end{array}$} \\
\hline $\begin{array}{l}\text { Subjects with } \\
\text { normal renal } \\
\text { function (8) }\end{array}$ & $\begin{array}{c}100.1 \\
\pm 19.90\end{array}$ & $\begin{array}{c}127.8 \\
\pm 16.63\end{array}$ & $\begin{array}{l}-27.8(+27.8 \%) \\
\pm 11.23\end{array}$ \\
$\begin{array}{l}\text { Patients with } \\
\text { CRI (5) }\end{array}$ & 17.4 & $41.8 \ddagger$ & $-24.4(+140.2 \%)$ \\
& \pm 5.87 & \pm 11.24 & \pm 6.34 \\
\hline
\end{tabular}

* Data are presented as mean $\pm \mathrm{SEM}$ in $\mu \mathrm{mol} / \mathrm{min} \cdot 1.73 \mathrm{~m}^{2}$.

f Significantly different from nitrogen extracted, $P<0.025$.
Findings obtained in normal controls demonstrate that the human kidney produces significant amounts of tyrosine. This production is of the same magnitude as that of muscular production, as can be calculated from data by Felig and Wahren $(29,30)$. Though the liver synthesizes large amounts of tyrosine, the net tyrosine balance across the hepatosplanchnic bed demonstrates a significant uptake of this AA (30). Hence in the postabsorptive state the kidney and the muscle participate almost equally in the release of significant amounts of tyrosine into the circulation. It is believed that tyrosine is produced by the kidney from phenylalanine through the phenylalanine 4-hydroxylase system (EC 1.14.16.1) (31). However, in our cases, the amount of phenylalanine extracted by the kidney is not sufficient to account for the amount of tyrosine produced.

Finally, an important finding is the renal release of taurine. Since this AA is significantly released into the circulation neither by muscular tissue nor by the hepatosplanchnic bed (6), it follows that in postabsorptive man the kidney appears to have a major role in homeostasis of circulating taurine. This AA may derive from cysteine, which in turn may derive from glutathione.

Our results demonstrate that chronic renal disease significantly affects both the uptake and the release of the same AA considered above under normal conditions. In addition, total renal production of ammonia, namely that excreted plus that added to renal venous blood, is decreased in relation to the reduction of functioning renal mass. In the same condition, renal glutamine extraction from whole blood is greatly decreased, as already shown by measuring A-RV differences in plasma glutamine $(5,22)$. In contrast to normal subjects, in patients with CRI only $35 \%$ of ammonia produced can be accounted for by the amount of glutamine extracted from arterial blood, even assuming that both $\mathrm{N}$ groups of glutamine are used for ammonia production. Accordingly, most of the ammonia produced must derive from substrates other than glutamine extracted 
from blood. In CRI the availability of glutamine supplied to the kidney through the arterial inflow does not seem to be rate limiting for ammonia production. In fact glutamine loads, administered orally (32) or intravenously (22), failed to enhance ammonia excretion in patients with CRI, whereas comparable loads given to normal controls induced a significant increase in ammonia excretion. In patients with CRI, the rate of renal ammonia production per unit of GFR is increased fourfold. Nevertheless, the rate of glutamine extraction per unit of GFR is not different from controls, despite the presence of chronic metabolic acidosis. These data demonstrate that the residual functioning renal tissue does not extract enough glutamine to account for the amount of ammonia produced. Moreover, if patients with CRI are compared with a group of subjects with normal renal function and $\mathrm{NH}_{4} \mathrm{Cl}$ induced chronic acidosis, elsewhere reported (5), it is possible to calculate that ammonia production per unit of GFR is similar in both groups $(116.0 \pm 20.70 \mu \mathrm{mol} / \mathrm{min}$ per $100 \mathrm{ml}$ GFR in $\mathrm{NH}_{4} \mathrm{Cl}$ acidosis vs. $89.2 \pm 9.92$ in $\mathrm{CRI}$ ), whereas glutamine extraction per unit of GFR is sevenfold higher in subjects with $\mathrm{NH}_{4} \mathrm{Cl}$ acidosis $(85.2 \pm 13.86 \mu \mathrm{mol} / \mathrm{min}$ per $100 \mathrm{ml} \mathrm{GFR}$ in $\mathrm{NH}_{4} \mathrm{Cl}$ acidosis vs. $12.6 \pm 10.62$ in CRI, $P<0.001$ ). All the above data strongly suggest that in CRI glutamine was inadequately used by the residual functioning tissue for ammonia production. The defective use might be dependent on an altered transport of glutamine into the mitochondria, the major sites for its use (33) and/or on an inhibition of glutaminases by some "uremic toxin". It has been shown that methylguanidine inhibits rat kidney phosphate-independent glutaminase activity (34). Further, in rats with subtotal nephrectomy, phosphatedependent glutaminase activity (EC 3.5.1.2.) per gram of tissue is significantly decreased despite an increased production rate of ammonia per residual nephron (35).

The net balance across the kidney of AA besides glutamine appears to be altered by renal disease. The absolute values of uptake or release of each AA are decreased with the exception of leucine. However, when extraction and production rates of each $\mathrm{AA}$ are calculated per unit of GFR, different behaviors are seen. Thus, alanine release is increased fourfold, citrulline uptake and arginine release are increased threefold compared to those measured in normal controls. Moreover, the relationship between citrulline uptake and arginine release is still present (Fig. 1), despite the quantitative variations of the net balance of these AA across the kidney. Accordingly, the conversion of citrulline into arginine seems fairly preserved. Likewise, the residual functioning renal tissue adds twice as much tyrosine to the venous blood compared to controls. On the contrary, proline extraction, and serine, threonine, and lysine release per unit of GFR are not different from controls, suggesting a defective nephron adaptation of the metabolism of these AA. A still more severe derangement is observed in the renal metabolism of glycine, taurine, phenylalanine, and ornithine, whose uptake or release disappear.

Data presented in this study suggest that the renal metabolic alterations induced by chronic disease may be responsible for changes of arterial levels of some AA, that were observed in patients with CRI considered here, and previously outlined (5, 36-39). Thus, the lower level of tyrosine in arterial blood in patients with CRI may be accounted for by decreased renal production, as suggested by the relationship between renal tyrosine release and arterial level of this AA (Fig. 2). The same may be inferred for serine. In addition, the higher arterial level of proline and glutamine may be partly dependent on a reduced use by the diseased kidney. On the contrary, the increased citrulline level measured in the arterial blood of these patients is likely not only dependent on the decreased renal uptake of this AA, inasmuch as arterial citrulline level shows a tendency to rise as renal uptake increases.

Striking differences between normal subjects and patients with CRI are revealed if one compares the net balance between the $\mathrm{N}$ contributed by AA extracted from the arterial blood, and the $\mathrm{N}$ contributed by AA added to the renal veins and by ammonia produced (Table VI). In CRI the amount of $\mathrm{N}$ released is more than twice as much as the amount of $\mathrm{N}$ taken up by the kidney. We think that the most reasonable explanation for the excess of $\mathrm{N}$ released by the kidney in patients with CRI is an intrarenal degradation of peptides, polypeptides, and low molecular weight proteins supplied to the kidney by the arterial inflow. The renal breakdown of these compounds and the presence in the kidney of specific degrading enzymes are largely supported by the literature (40). Nitrogen balance across the kidney reported here suggests that the renal breakdown of these substances is increased in CRI. Such a breakdown releases free AA, which may be added to renal vein blood and/or conveyed to various metabolic fates, including ammonia production. The comparison between the rate of ammonia production and the rate of AA extraction in CRI supports such a hypothesis. In fact, the $\mathrm{N}$ groups deriving from glutamine and proline extracted from the arterial blood can account for not more than $50 \%$ of ammonia produced by the kidney. Citrulline is not included in this calculation because it seems to be used mainly for arginine production and it does not produce ammonia in vitro (unpublished observations), whereas proline may be an ammonia precursor through conversion into glutamate (41). Therefore, it may be presumed that approximately half of the ammonia produced in CRI derives from precursors made available by protein and peptide degradation within the kidney. Consequently, it seems likely 
that in CRI glutamine supplied to the kidney by arterial blood is no longer the major ammonia precursor.

\section{ACKNOWLEDGMENTS}

The authors wish to thank Mr. Mario Bruzzone for his excellent technical assistance. The authors are indebted to Mrs. Francesca Tincani for preparation of the manuscript. Some of the results reported in this paper were discussed with Dr. Arnold S. Relman (Department of Medicine, Joslin Research Laboratory, Harvard Medical School, Boston, Mass.) and with Dr. Robert G. Narins (Division of Nephrology, Peter Bent Brigham Hospital, Boston, Mass.) to whom the authors are grateful for advice and criticism.

This study was supported by grants 37/73.01102.65, 39/74.00860.65, and 42/77.01578.65 from the Consiglio Nazionale delle Ricerche under the co-operative agreement between Italy and the United States of America.

\section{REFERENCES}

1. Pitts, R. F. 1973. Production and excretion of ammonia in relation to acid-base regulation. In Renal Physiology. J. Orloff and R. W. Berliner, editors. American Physiological Society, Washington. 15: 45.5-496.

2. Owen, E. E., and R. R. Robinson. 1963. Amino acid extraction and ammonia metabolism by the human kidney during the prolonged administration of ammonium chloride. J. Clin. Invest. 42: 263-276.

3. Pitts, R. F., A. C. Damian, and M. B. MacLeod. 1970. Synthesis of serine by rat kidney in vivo and in vitro. Am. J. Physiol. 219: 584-589.

4. Pitts, R. F., and W. J. Stone. 1967. Renal metabolism of alanine. J. Clin. Invest. 46: 530-5.38.

5. Tizianello, A., G. De Ferrari, G. Garibotto, and G. Gurreri. 1978. Effects of chronic renal insufficiency and metabolic acidosis on glutamine metabolism in man. Clin. Sci. Mol. Med. 55: 391-397.

6. Felig, P., J. Wahren, and L. Raf. 1973. Evidence of interorgan amino acid transport by blood cells in humans. Proc. Natl. Acad. Sci. U. S. A. 70: 1775-1779.

7. Perry, T. L., and S. Hansen. 1969. Technical pitfalls leading to errors in the quantitation of plasma amino acids. Clin. Chim. Acta. 25: 53-58.

8. Lund, P. 1974. L-glutamine: determination with glutaminase and glutamate dehydrogenase. In Methods of enzymatic analysis. H. U. Bergmeyer, editor. Academic Press, Inc., New York. 2nd edition. IV: 1719-1722.

9. Graham, L. T., Jr., and M. H. Aprison. 1966. Fluorometric determination of aspartate, glutamate and gammaamino-butirate in nerve tissue using enzymic methods. Anal. Biochem. 15: 487-497.

10. Chaney, A. L., and P. E. Marbach. 1962. Modified reagents for determination of urea and ammonia. Clin. Chem. 8: 130-132.

11. Brun, C. 1950. Thiosulphate determination in kidne'y function test. J. Lab. Clin. Med. 35: 152-154.

12. Smith, H. W., W. Goldring, and H. Chasis. 1938. The measurement of tubular excretory mass, effective blood How and filtration rate in the normal human kidney. J. Clin. Invest. 17: 263-266.

13. Wolf, A. W. 1941. Total renal blood flow at any urinary How or extraction fraction. Am. J. Physiol. 133: 496-497.

14. Bergmeyer, H. U., E. Bernt, M. Grassel, and G. Michal. 1974. Evaluation of experimental results. In Methods of enzymatic analysis. H. U. Bergmeyer, editor. Academic Press, Inc., New York. 2nd edition. I: $308-317$.

15. Hagenfeldt, L., A. Larsson, and R. Andersson. 1978. The $\gamma$-glutamyl cycle and aminoacid transport. N. Engl.J. Med. 299: $587-590$.

16. Snedecor, G. W., and W. G. Cochran. 1967. Statistical methods. Iowa State University Press, Ames, Iowa. 6th edition.

17. Felig, P., O. E. Owen, J. Wahren, and G. Cahill, Jr. 1969. Amino acid metabolism during prolonged starvation. $J$. Clin. Invest. 48: 584-594.

18. Elwyn, D. H. 1966. Distribution of amino acids between plasma and red blood cells in the dog. Fed. Proc. 25: $8.54-861$.

19. Elwyn, D. H., W. J. Launder, H. C. Parikh, and E. M. Wise, Jr. 1972. Roles of plasma and erythrocytes in interorgan transport of amino acids in dogs. Am. J. Physiol. 222: $133.5-1342$.

20. Winter, C. G., and H. N. Christensen. 1964. Migration of amino acids across the membrane of the human erythrocyte. J. Biol. Chem. 239: 872-878.

21. Skalsky, M., K. Schindhelm, and P. C. Farrel. 1978. Creatinine transfer between red cells and plasma: a comparison between normal and uremic subjects. Nephron. 22: 514-521.

22. Tizianello, A., G. De Ferrari, G. Gurreri, I. Bertocchi, and G. Garibotto. 1975. L'incapacità del rene ad utilizzare la glutamina per la produzione di ammoniaca nell'insufficienza renale cronica. Minerva Nefrol. 22: 138-147.

23. Squires, E. J., D. E. Hall, and J. T. Brosnan. 1976. Arteriovenous differences for amino acids and lactate across kidney of normal and acidotic rats. Biochem. J. 160: $125-128$.

24. Shalhoub, R., W. Webber, S. Glabman, M. Canessa-Fisher, J. Klein, J. De Haas, and R. F. Pitts. 1963. Extraction of amino acids from and their addition to renal blood plasma. Am. J. Physiol. 204: 181-186.

25. Sekura, R., and A. Meister. 1974. Glutathione turnover in the kidney; considerations relating to the $\gamma$-glutamyl cycle and the transport of amino acids. Proc. Natl. Acad. Sci. U. S. A. 71: 2969-2972.

26. Wendel, A., R. Hahn, and W. G. Guder. 1976. On the role of $\gamma$-glutamyltransferase in renal tubular amino acid reabsorption. In Renal metabolism in relation to renal function. U. Schmidt and U. C. Dubach, editors. Huber Medical Publisher, Berne, Switzerland. 426-435.

27. Ratner, S., and B. Petrack. 195.3. The mechanism of arginine synthesis from citrulline in kidney.J. Biol. Chem. 200: $175-185$.

28. Rogers, Q. R., R. A. Freedland, and R. A. Symmons. 1972. In vivo synthesis and utilization of arginine in the rat. Am. J. Physiol. 223: 236-240.

29. Felig, P., and J. Wahren. 1971. Amino acid metabolism in exercising man. J. Clin. Invest. 50: 2702-2714.

30. Wahren, J., P. Felig, and L. Hagenfeldt. 1976. Effect of protein ingestion on splanchnic and leg metabolism in normal man and in patients with diabetes mellitus. $J$. Clin. Invest. 57: 987-999.

31. Tourian, A., J. Goddard, and T. T. Puck. 1969. Phenylalanine hydroxylase activity in mammalian cells. J. Cell. Physiol. 73: 159-170.

32. Welbourne, T., M. Weber, and N. Bank. 1972. The effect of glutamine administration on urinary ammonium excretion in normal subjects and in patients with renal disease. J. Clin. Invest. 51: 1852-1860.

33. Katunuma, N., L. Tomino, and H. Nishino. 1966. Glutaminase isozymes in rat kidney. Biochem. Biophys. Res. Commun. 22: 321-328. 
34. Acquarone, N., A. Tizianello, G. De Ferrari, M. Bruzzone, A. Papio, and G. Garibotto. 1977. Inibizione della glutaminasi fosfato-indipendente da parte della metilguanidina e sue ripercussioni sull'ammoniogenesi renale. Minerva Nefrol. 24: 341-344.

35. Benyajati, S., and L. Goldstein. 1978. Relation of ammonia excretion adaptation to glutaminase activity in acidotic, subtotalnephrectomized rats. Kidney Int. 14: 50-57.

36. Gulyassy, P. F., A. Aviram, and J. H. Peters. 1970. Evaluation of amino acid and protein requirements in chronic uremia. Arch. Intern. Med. 126: 855-859.

37. McGale, E. H. F., J. C. Pickford, and G. M. Aber. 1972. Quantitative changes in plasma amino acids in patients with renal disease. Clin. Chim. Acta. 38: 395-403.
38. Ganda, O. P., T. T. Aoki, J. S. Soeldner, R. S. Morrison, and G. F. Cahill, Jr. 1976. Hormone-fuel concentrations in anephric subjects. Effect of hemodialysis (with special reference to amino acids). J. Clin. Invest. 57: 1403-1411.

39. Nadvornikovà, H., O. Schüch, J. Maly, J. Pechar, P. Dobersky, and D. Tomkova. 1978. Renal clearance of amino acids in patients with severe chronic renal failure. $\mathrm{Ne}$ phron. 20: 83-89.

40. Maak, T. 1975. Renal handling of low molecular weight proteins. Am. J. Med. 58: 57-64.

41. Krebs, H. A. 1933. Untersuchungen uber den Stoffwechsel der Aminosauren im Tierkorper. Z. Physiol. Chem. 217: 191-227. 